\title{
In Vitro Characterization of Chitosan-Based Particles as Carrier of Influenza Viral Antigens
}

\author{
Mehmet Karaaslan, Kadir Turan* \\ 'Marmara University, Faculty of Pharmacy, Department of Basic Pharmaceutical Sciences, Istanbul, Turkey
}

Please cite this article as: Karaaslan M, Turan K. In Vitro Characterization of Chitosan-Based Particles as Carrier of Influenza Viral Antigens. Eur J Biol 2018; 77(1): 1-10.

\begin{abstract}
Objective: Chitosan is a natural polysaccharide derived from chitin by deacetylation. It is a non-toxic, biocompatible and biodegradable polymer, and has attracted considerable interest in a wide range of pharmaceutical applications including drug and vaccine delivery. The immune-stimulating activity of chitosan microparticles such as the activation of macrophages and polymorphonuclear leukocytes has been reported. In this work, we have investigated the releasing properties of influenza virus antigens from the chitosan microparticles and beads.
\end{abstract}

Materials and Methods: Chitosan microparticles and beads were prepared by coacervation and ionotropic gelation method, respectively. The microparticles and beads were loaded with the viral antigens by passive adsorption and/or entrapment into the microparticles. The titration of the viruses was defined by haemagglutination assay or by quantitation of viral proteins using the Bradford method.

Results: The results showed that the loading efficiency and the loading capacity of chitosan microparticles/beads with the viral antigens and the releasing profiles of the antigens from the particles changed depending on the type of chitosan, the $\mathrm{pH}$ of the loading buffer and the methods used to prepare the particles. The influenza viral antigens, passively adsorbed onto microparticles/beads, were released within 2 hours to 5 days. In contrast, the viral antigens entrapped into the chitosan microparticles were released more slowly and continued for up to 30 days.

Conclusion: It was concluded from the viral antigen releasing profiles of chitosan particles that the viral antigens entrapped into the microparticles are more suitable for in vivo applications as a potential mucosal vaccine.

Keywords: Chitosan, mucosal vaccines, influenza A viruses, microparticles, beads

\section{INTRODUCTION}

Chitin, the main source of chitosan, is the second most abundant polysaccharide in nature (1). It is the principal component of the exoskeletons of crustaceans and insects as well as of cell walls of fungi and some bacteria (2-4). Chitosan [(1-4)-2-amino-2-deoxy-b-D-glucan] is obtained by the alkaline deacetylation of chitin $(1,5)$. Chitosan is a positively charged biopolymer, which can form complexes with the negatively charged molecules (6-8). It is a safe and non-toxic linear molecule composed of randomly distributed $\beta$ - $(1 \rightarrow 4)$-linked D-glucosamine and $\mathrm{N}$-acetyl-D-glucosamine. All these characteristics make the chitosan an ideal biopolymer for formulation and controlled release of some drugs and vaccines. A number of studies have been carried out with the aim of using chitosan-based microparticles as a carrier of drugs, vaccines and even plasmid DNA (7-11). Some studies have shown that chitosan plays a role in the activation of macrophages and cytotoxic T lymphocytes $(12,13)$. Due to these immune-stimulatory effects, chitosan is of great importance, especially in research into the development of mucosal vaccines $(11,14)$. In this study, the potential of chitosan as a carrier for influenza A viruses, which pose a great risk for human health, was investigated. These viruses characteristically cause recurrent epidemics of diseases resulting in considerable mortality and morbidity worldwide each year, especially among high-risk groups such as the elderly and young children $(15,16)$. This is largely due to the continual changes in the antigenic properties of influenza viruses via minor and major antigenic changes (17). In particular, the changes of the viral hemagglutinin proteins enable the virus to avoid the immunolog- 
ical defense of the host organism. Consequently, the control of the influenza viruses by vaccination is not completely effective. However, vaccines are one of the most important tools to deal with influenza virus infections. Current commercially available influenza vaccines are the formulations of live attenuated viruses (attenuated vaccines), inactivated viruses (whole inactivated or split vaccines), or purified viral surface antigens (subunit vaccines) (18-19). However, different approaches to developing more effective vaccines against influenza virus infections, such as mucosal vaccines have been considered in several studies (20). In this context, the nasal mucosa is an attractive site for the delivery of vaccines, and it has certain advantages over the other application routes $(21,22)$. Mucoadhesive particulate carrier systems such as chitosan, starch and hyaluronic acid offer significant potential for the development of mucosally administered vaccines $(23,24)$. Particulate carriers based on chitosan, a biodegradable polymer, have great potential for the delivery of viral proteins for vaccination. The incorporation or adsorption of the viral antigens onto the chitosan particles was recently shown to have a good adjuvant effect (25-27). Chitosan could open the intercellular tight junctions and facilitate the paracellular transport of macromolecules; nano- and microparticles are suitable for controlled vaccine release $(28,29)$. Thus, chitosan and its derivatives could induce strong systemic and mucosal immune responses against viral antigens (13). In the present study, we have investigated the potential of chitosan for the sustained release of influenza viral antigens. We have prepared chitosan microparticles/beads loaded with influenza viral antigens, and examined the releasing behavior of the viral antigens from microparticles/beads in in vitro conditions.

\section{MATERIAL AND METHODS}

\section{Chitosan}

Chitosan biopolymers were purchased from Fluka Co. Ltd, Switzerland. Two types of chitosan were used for the formation of chitosan microparticles and beads; low-viscous chitosan (L-chitosan / Cat. No. 50494 / <200 mPa.s; $1 \%$ solution in $1 \%$ acetic acid at $20^{\circ} \mathrm{C}$ ) and middle-viscous chitosan (M-chitosan / Cat. No. 28191 / 200$400 \mathrm{mPa} . \mathrm{s} ; 1 \%$ solution in $1 \%$ acetic acid at $20^{\circ} \mathrm{C}$ ) with $150 \mathrm{kD}$ and $400 \mathrm{kD}$ average molecular weight, respectively. Chitosan solutions $0.5 \%(\mathrm{w} / \mathrm{v})$ and $2 \%(\mathrm{w} / \mathrm{v})$ were prepared by dissolving $0.5 \mathrm{~g}$ and $2 \mathrm{~g}$ of chitosan in $100 \mathrm{ml}, 1 \%(\mathrm{v} / \mathrm{v})$ acetic acid.

\section{Influenza Viruses, Growth, Purification and Quantitation}

The Influenza virus A/Puerto Rico/8/34 (H1N1) was used in the present experiments. The viruses were grown in the allantoic cavity of 10 day-old embryonated eggs. Using a syringe with a 25-gauge needle, $0.1 \mathrm{ml}$ of virus sample (100-200 pfu) diluted in phosphate buffer solution (PBS) supplemented with bovine serum albumin-fraction $\mathrm{V}(1 \%, \mathrm{w} / \mathrm{v})$ was inoculated into the allantoic cavity of hen eggs. The inoculated eggs were incubated at $35.5^{\circ} \mathrm{C}$ for 48 hours. The allantoic fluid collected from 25 eggs was harvested and clarified by centrifugation at 3,000 g for 10 minutes. The viruses were concentrated with polyethylene glycol (PEG) precipitation. For this procedure, solid PEG-6000 was added to the virus containing fluid at a final concentration of
$8 \%(\mathrm{w} / \mathrm{v})$ and stirred on ice for $1 \mathrm{~h}$. The virus precipitate was recovered by centrifugation at $10.000 \mathrm{~g}$ for $30 \mathrm{~min}$ at $4^{\circ} \mathrm{C}$ and resuspended in $1 \mathrm{ml}$ of NTE $(100 \mathrm{mM} \mathrm{NaCl}, 1 \mathrm{mM}$ Tris HCL, pH 7.5, 1 mM EDTA) buffer. The viruses were purified by ultracentrifugation on a sucrose cushion. A two-layer sucrose solution was

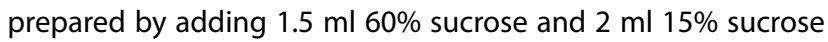
solutions into the $4 \mathrm{ml}$ ultracentrifuge tubes (Sorvall TST 60.4 Swing Out Rotor) and, $0.5 \mathrm{ml}$ of the concentrated virus sample was layered over the $15 \%$ sucrose solution. The samples were centrifuged at $100.000 \mathrm{~g}$ for 1 hour at $4^{\circ} \mathrm{C}$, and the viruses concentrated in the interface region between $15 \%$ sucrose layer and $60 \%$ sucrose cushion was removed. The virus fraction was diluted to $4 \mathrm{ml}$ with NTE buffer and re-centrifuged $100.000 \mathrm{~g}$ for $30 \mathrm{~min}$ at $4^{\circ} \mathrm{C}$. The virus precipitate was resuspended in $0.5 \mathrm{ml}$ NTE buffer and stored as small aliquots at $80^{\circ} \mathrm{C}(30)$. The purified influenza viruses were titrated with haemagglutination assays. $A$ doubling dilutions of virus sample in $100 \mu \mathrm{L}$ of PBS was prepared in 96 -well U-bottom plate. Equal volume of $1 \%$ red blood cell was added to diluted samples and allowed to stand undisturbed for $30 \mathrm{~min}$. After incubation, the haemagglutination in endpoint dilution was defined and, the virus titer was calculated as haemagglutination unit (HAU) with the following equation (30).

Virus quantity $(\mathrm{HAU} / 100 \mu \mathrm{L})=(A+B / 2)$

$A$, the end-point dilution factor giving positive haemagglutination; $B$, the first-point dilution factor giving negative haemagglutination.

\section{Testing of Influenza Virus Purity}

The purity of the prepared virus sample was checked by both the analysis of viral structural proteins by sodium dodecyl sulfate - polyacrylamide gel electrophoresis (SDS-PAGE) technique and electron microscopic analysis. For SDS-PAGE analysis, the virus samples were mixed with $x 4$ SDS sample loading buffer at a ratio of 3:1, then denatured for 5 minutes in boiling water and, loaded onto $7.5 \%$ polyacrylamide gel. The electrophoresis was carried out in the first 20 minutes at $10 \mathrm{~mA} / \mathrm{gel}$ and then at 20 $\mathrm{mA} / \mathrm{gel}$ for 2 hours. The proteins separated on gel were visualized by staining with Coomassie brilliant blue R-250. For electron microscopic analysis, virus samples were negatively stained (31) and electron micrographs of viruses were taken with a transmission electron microscope (Jeol T-100).

\section{Inactivation of the Influenza A Viruses}

Formaldehyde and $\beta$-propiolactone are widely used for inactivation of viruses for the preparation of vaccines (32). In this work, formaldehyde was used for the inactivation of purified influenza viruses. Formaldehyde was added to the virus samples at $0.1 \%$ final concentration and incubated at $4^{\circ} \mathrm{C}$ for a week. The inactivated virus sample was used for entrapment in chitosan microparticles.

\section{Preparation of Chitosan Microparticles}

Chitosan solution $0.5 \%(\mathrm{w} / \mathrm{v})$ was prepared by dissolving $0.2 \mathrm{~g}$ of L- or M-chitosan in $20 \mathrm{ml}, 1 \%$ (v/v) acetic acid. For the formation of chitosan microparticle, an equal volume of $20 \%$ sodium sulfate solution was added dropwise to the chitosan solutions 
and mixed on a magnetic stirrer for 1 hour. To strengthen the microparticles, glutaraldehyde was added to the solution at $0.1 \%$ final concentration and stirring continued for 45 minutes. Then, the chitosan microparticles were recovered by centrifugation $\left(10.000 \mathrm{~g}, 4^{\circ} \mathrm{C}, 20 \mathrm{~min}\right)$, and repeatedly washed with deionized water. Chitosan microparticles were freeze-dried by using a freeze dryer, passed through a sieve with $53 \mu \mathrm{m}$ mesh size and stored in a desiccator at $4^{\circ} \mathrm{C}$. The average sizes of microparticles was determined using a light microscope with an ocular micrometer by measuring at least 100 particles.

\section{Preparation of Chitosan Beads}

The chitosan beads were prepared by the ionotropic gelation method (33) using sodium tripolyphosphate (TPP) as an ionic agent. For this, a $2 \%$ chitosan solution prepared in $1 \%$ acetic acid was used. The chitosans solution was dropped into the 10\% TPP solution ( $\mathrm{pH} 6$ or $\mathrm{pH}$ 9) stirred at $140 \mathrm{rpm}$ using a syringe with a 22-gauge needle under a constant pressure applied on the syringe to get the beads in uniform sizes. The chitosans beads were cross-linked with $1 \% \mathrm{w} / \mathrm{v}$ of glutaraldehyde and repeatedly washed with deionized water. The beads were dried at room temperature or freeze-dried with a freeze-dryer. The average sizes of chitosan beads was determined using a light microscope with an ocular micrometer by measuring at least 25 beads.

\section{Scanning Electron Microscopic Examination of Chitosan Beads}

The surface characteristics and porosity of the chitosan beads were examined with a scanning electron microscope (SEM). The beads were coated with $20 \mathrm{~nm}$ of gold and, images were taken with SEM (JSM 5200).

\section{Loading of the Chitosan Microspheres with Influenza Viruses}

The chitosan microparticles were loaded with purified influenza viruses by following two methods. First, the chitosan microparticles, prepared as mentioned above, were loaded with viruses by passive adsorption. $7.5 \mathrm{mg}$ of the chitosan microparticles were added to $1 \mathrm{ml}$ PBS containing influenza viruses equivalent to the $1920 \mathrm{HAU}$ virus and mixed with a tube mixer at $30 \mathrm{rpm}$ for 5 hours at room temperature. Then the microparticles were precipitated by centrifugation at $10,000 \mathrm{~g}$ for $10 \mathrm{~min}$. The supernatants were removed and used for the titration of unabsorbed viruses to the chitosan microparticles. Virus titration in the supernatants were determined with HA assay. The microparticle precipitates were used in releasing experiments.

In the second method, the viruses were entrapped in the chitosan microparticles during the preparation processes. An inactivated influenza virus sample equivalent to $40000 \mathrm{HAU}(\sim 220$ $\mu \mathrm{g}$ of viral protein) was added to $20 \mathrm{ml}$ of $10 \%$ sodium sulfate and this solution was used for the preparation of microparticles as described above. Then the microparticles were precipitated by centrifugation at $10,000 \mathrm{~g}$ for $10 \mathrm{~min}$. The supernatants were removed and used for the titration of unentrapped viruses by measuring viral proteins using the Bradford method. The precipitates were washed with deionized water, freeze-dried, passed through a sieve with $53 \mu \mathrm{m}$ mesh size and stored in a desiccator at $4^{\circ} \mathrm{C}$. The microparticle sizes was determined using a light microscope with an ocular micrometer by measuring at least 100 particles.

The loading efficiency (i) and loading capacity (ii) of microparticles were calculated with the following equations as previously described $(34,35)$.
i. Loading (encapsulation) efficiency (\%) $=(A-B / A) .100$
ii. Loading (encapsulation) capacity (HAU or $\mu \mathrm{g}$ viral protein /mg microparticles $)=(A-B / C)$

$A$, the total amount of viruses (HAU or $\mu \mathrm{g}$ viral protein); $B$, unabsorbed or unentrapped virus quantity (HAU or $\mu \mathrm{g}$ viral protein); $\mathrm{C}$, the weight of chitosans microparticles or beads (mg).

\section{Loading of the Chitosan Beads with Influenza Viruses}

The chitosan beads were loaded with the purified viruses by the passive adsorption at three different $\mathrm{pH}$ (pH 5, 7 and 9). $20 \mathrm{mg}$ of the chitosan beads and purified influenza viruses equivalent to $1920 \mathrm{HAU}$ were mixed in $1 \mathrm{ml}$ PBS at different $\mathrm{pH}$ and rotated with a tube mixer at $30 \mathrm{rpm}$ for 5 hours at room temperature. Then the liquid phase was completely removed and used for the titration of the unabsorbed virus with HA assay. The virus loaded chitosan beads were used in the releasing experiments.

\section{In vitro Release Studies}

The influenza virus release from the loaded chitosan microparticles and beads was studied in PBS using the shaking water bath, $60 \mathrm{rpm}$ at $37^{\circ} \mathrm{C}$. The microparticle samples were centrifuged at $10,000 \mathrm{~g}$ for $10 \mathrm{~min}$ at defined time intervals and, $200 \mu \mathrm{L}$ of sample from the supernatant was removed for virus titration with $\mathrm{HA}$ assay or viral protein quantitation using the Bradford method. In release studies with chitosan beads, $200 \mu \mathrm{L}$ samples from the liquid phase were directly removed without centrifugation and used for the titration of viruses with HA assay. After taking the samples, $200 \mu \mathrm{L}$ of fresh PBS was added to the medium and the incubation continued. The cumulative release of the viruses as $\mathrm{HAU}$ or $\mu \mathrm{g}$ viral proteins was determined and plotted to time intervals.

\section{Statistical Analysis}

Statistical methods used in this work include descriptive statistics (arithmetic mean and standard deviation) and the nonparametric Mann-Whitney test. $p<0.05$ defined statistical significance.

\section{RESULTS}

\section{The Titer and Purity of Influenza A Viruses}

The influenza $A$ viruses obtained from virus infected allantoic fluids of 25 embryonated hen eggs were purified by centrifugation on sucrose cushion and concentrated in $500 \mu \mathrm{L}$ of NTE buffer. The titer of the purified virus sample was detected by haemagglutination assay as $19200 \mathrm{HAU} / 100 \mu \mathrm{L}(12800+25600$ $/ 2$ = 19200) (Figure 1a). Inactivation with formalin and/or entrapment of influenza A viruses in chitosan microparticles inhibit the haemagglutination ability of the viruses (data not 
shown). The virus titrations were determined by quantifying viral protein using the Bradford method in experiments carried out with virus-entrapped chitosan microparticles. Therefore, a standard plot showing the viral protein quantity in the samples with a defined virus titer (as HAU) was generated (Figure 1b).

The purity of influenza A viruses prepared from embryonated hen eggs were checked both by an analysis of viral structural proteins with SDS-PAGE (Figure 2a) and electron microscopic observation of the negatively stained virus particles (Figure $2 b$ ). As shown in Figure 2a, the virus sample prepared by centrifugation at sucrose chosen was found to be very pure compared to infected crude allantoic fluid. The transmission electron microscopic observation (Jeol T-100) of the negative stained virus samples supported the purity of the viruses and gave information about the morphology of purified virus particles (Figure 2b). Hereby, it has been shown that viruses are highly purified from impurities such as cellular debris, and they have typical influenza virus morphology.

\section{The Sizes of the Chitosan Microparticles}

The sizes of virus-free (unloaded) and virus-entrapped microparticles prepared with two different types of chitosan ( $L$ - and M-chitosan) were determined using a light microscope with an ocular micrometer. The size of a minimum of 100 independent microparticles were measured from each formulation and the average sizes are given in Table 1. It was observed that the size of chitosan microparticles varied depending on the type of chitosan used. The chitosan microparticles prepared with $\mathrm{M}$-chitosan were found to be larger than those of L-chitosan but not
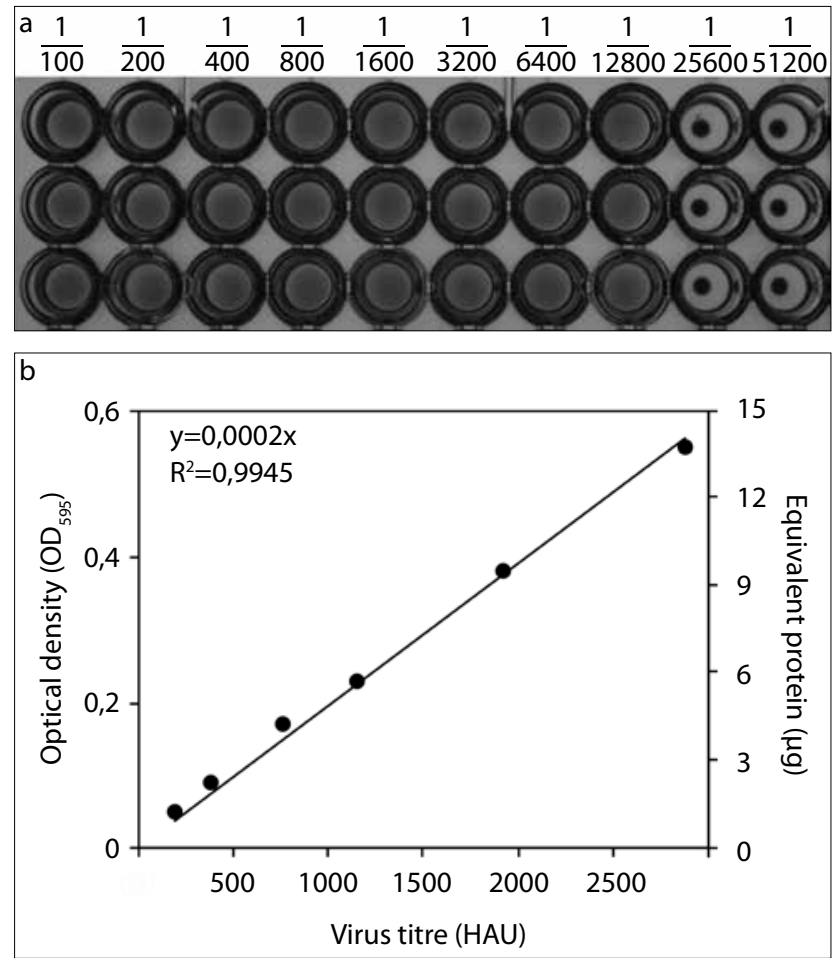

Figure 1. a, b. a) Titration of influenza $A$ viruses by haemagglutination assay; and $b$ ) Bradford method. statistically significant. Furthermore, the addition of viruses during microparticle preparation caused the formation of larger microparticles in size $(p<0.05)$.

\section{The Sizes and Morphological Analysis of Chitosan Beads}

The sizes of the beads prepared with $2 \%$ L-chitosan and M-chitosan solutions at two different $\mathrm{pH}$ were determined using a light microscope with an ocular micrometer in the way as the
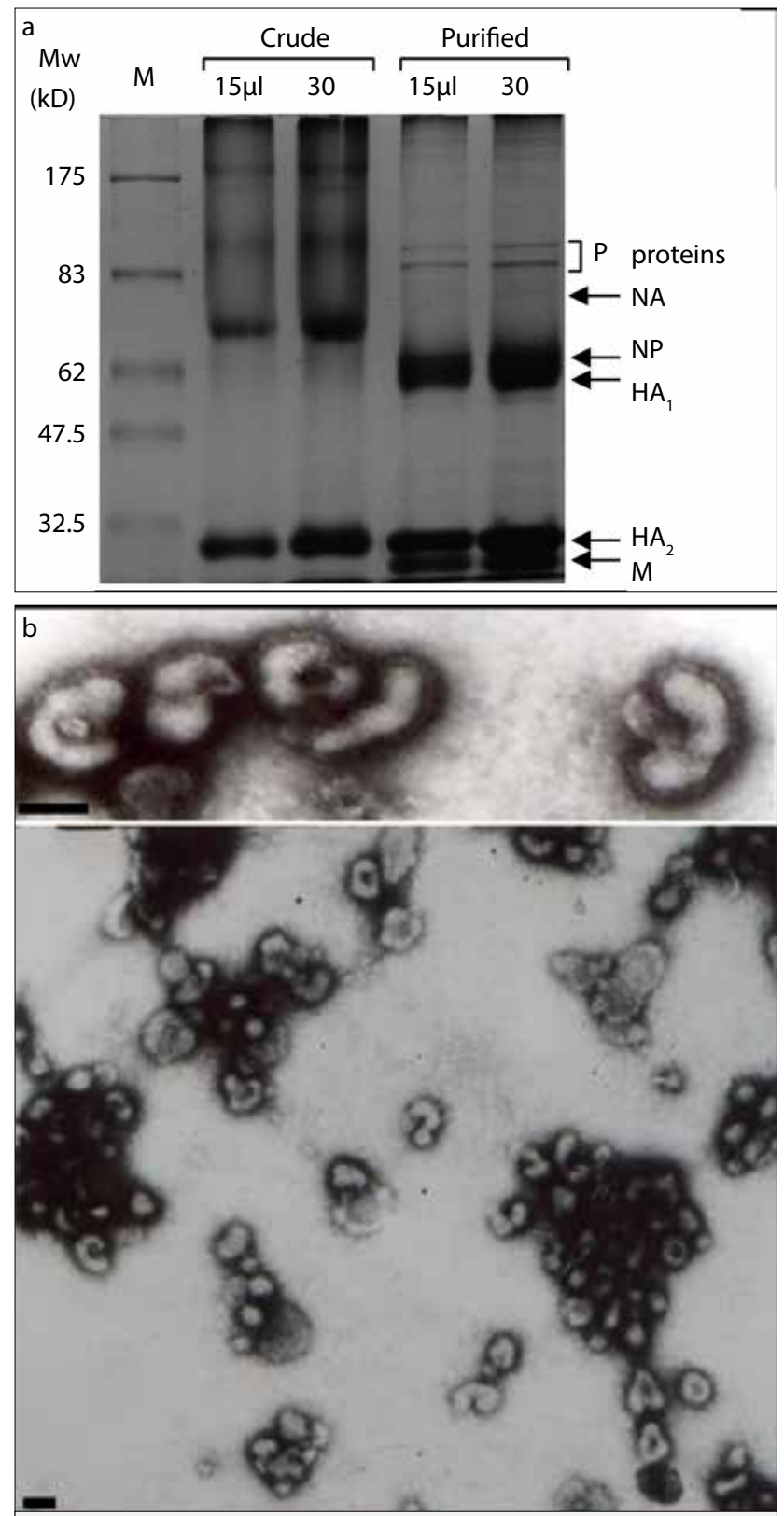

Figure 2. a, b. a) Checking of the purity of influenza A viruses produced in embryonated hen eggs by analysis of viral proteins with polyacrylamide gel electrophoresis; and b) electron microscopic observations. M.prestained protein marker (NEB, broad range). For electron microscopic observation, the purified viruses were negatively stained with $1 \%$ ammonium molybdate. The bar represents $100 \mathrm{~nm}$. 
Table 1. The sizes of chitosan microparticles prepared with L-chitosan (LM) and M chitosan (MM). LMv and MMv samples were loaded with inactivated influenza virus particles during microparticle preparation. $n \geq 100$.

\begin{tabular}{lcccc}
\hline formulation codes & LM & MM & LMv & MMv \\
\hline Size $(\mu \mathrm{m})$ & $1.57 \pm 0.1$ & $1.68 \pm 0.12$ & $1.78 \pm 0.15$ & $1.9 \pm 0.16$ \\
\hline
\end{tabular}

Table 2. The sizes of chitosan beads prepared with L-chitosan and M-chitosan. LBA and MBA beads were prepared at pH.6; LBB and MBB beads were prepared at $\mathrm{pH} 9 . \mathrm{n} \geq 25$.

\begin{tabular}{llllll}
\hline & formulation codes & LBA & LBB & MBA & MBB \\
\hline Size $(\mathrm{mm})$ & (lyophilized) & $1.40 \pm 0.04$ & $1.53 \pm 0.05$ & $1.47 \pm 0.04$ & $1.62 \pm 0.06$ \\
\hline & (dried at r. t.) & $0.62 \pm 0.02$ & $0.70 \pm 0.03$ & $0.66 \pm 0.02$ & $0.74 \pm 0.03$ \\
\hline
\end{tabular}
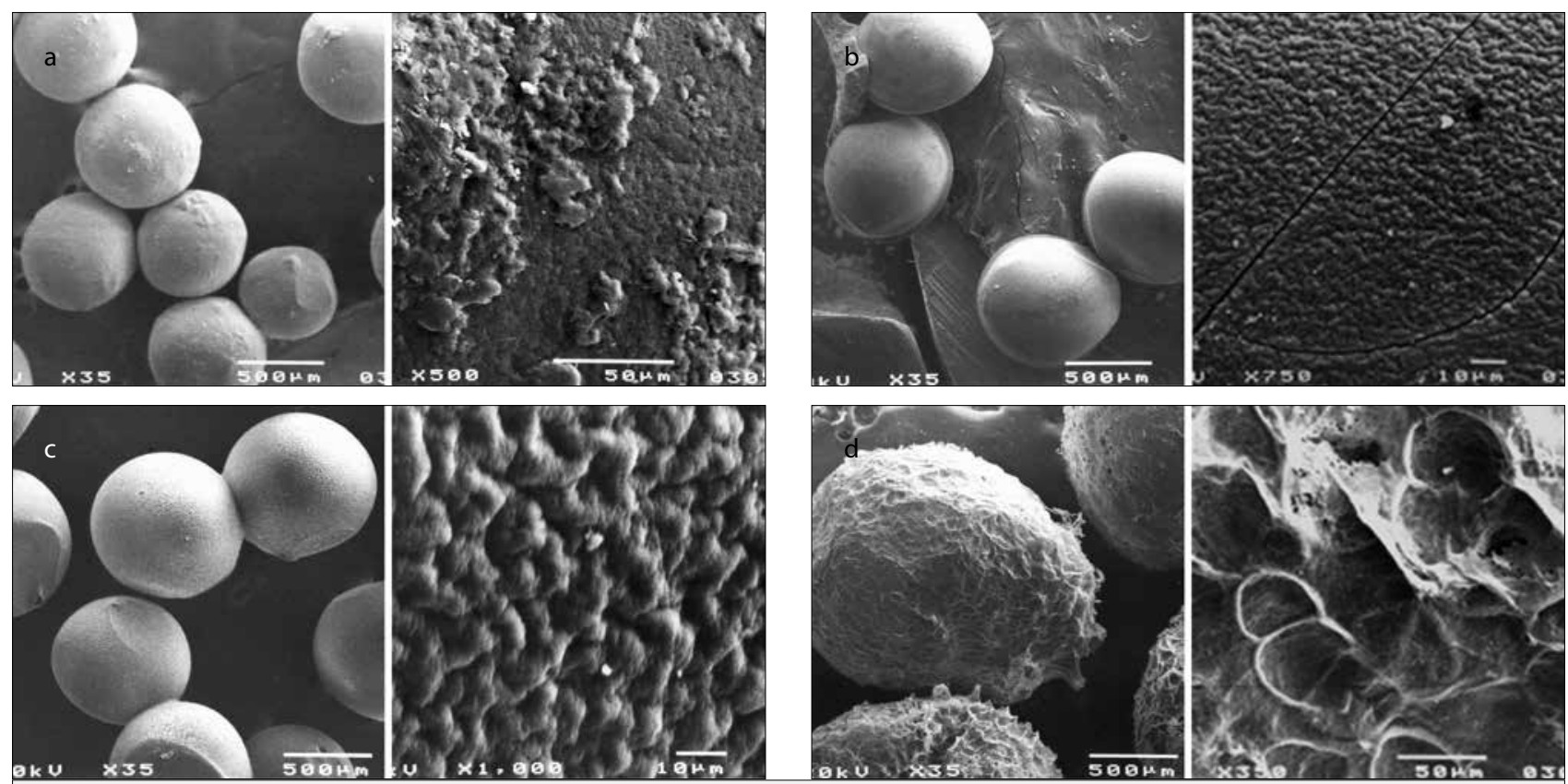

Figure 3. a-d. SAM images of chitosan beads prepared under different conditions. The samples dried at room temperature: a) LBA, b) $M B A, c) M B B ; d)$ freeze-dried sample: LBB.

microparticles. The sizes of beads varied depending on the $\mathrm{pH}$ of the TPP solution used for the bead formation and drying method rather than the type of chitosan as shown in Table 2. It was found that the beads prepared at $\mathrm{pH} 6$ (LBA and MBA) were smaller than the beads prepared at $\mathrm{pH} 9$ (LBB and MBB) ( $p>0.05$ ), and lyophilized beads were 2-3 times larger than the beads dried at room temperature $(p<0.05)$. The surface morphologies of chitosan beads prepared under different conditions were also examined by SEM (Figure 3). The dimensions of the chitosan beads observed with SEM were close to the values obtained with light microscopy. In addition, it was observed that the chitosan beads prepared with TPP at basic $\mathrm{pH}$ have more porous surface compering to those prepared at acidic $\mathrm{pH}$ (Figures 3a, 3b and 3c); the lyophilized beads were larger than the beads dried at room temperature and had irregular spongy shapes (Figure 3d).

\section{The Virus Loading Efficiency and Loading Capacity of Microparticles}

Chitosan microparticles were loaded with influenza viral antigens by passive adsorption or entrapping of inactivated virus particles during the preparation of microparticles. The antigen loading efficiency of microparticles loaded by passive adsorption was determined by measuring the titer of unabsorbed viruses with HA assay. It was found that microparticles prepared using L-chitosan had higher loading efficiency than those prepared with M-chitosan. Furthermore, the $\mathrm{pH}$ of the loading medium affected the loading efficiency of microparticles. The loading efficiency of microparticles was found to be higher at $\mathrm{pH}-7$ than that at $\mathrm{pH}-5$ and $\mathrm{pH}-9$ of the medium $(\mathrm{pH}: 7>5>9)(\mathrm{p}<0.05)$. The loading capacity of microparticles were found in correlation with loading efficiency (Table 3). 
Table 3. Virus loading efficiency and loading capacity of microparticles. Microparticles $(7.5 \mathrm{mg})$ were loaded with purified influenza A viruses (1920 HAU) by passive adsorption

\begin{tabular}{lccc}
\hline $\begin{array}{l}\text { formulation } \\
\text { codes }\end{array}$ & $\begin{array}{c}\text { loading } \\
\mathbf{p H}\end{array}$ & $\begin{array}{c}\text { loading } \\
\text { efficiency } \\
\text { (\%) }\end{array}$ & $\begin{array}{c}\text { loading capacity } \\
\text { (HAU/mg } \\
\text { microparticles) }\end{array}$ \\
\hline \multirow{2}{*}{ LM } & 5 & $82.5 \pm 4.1$ & $224.0 \pm 10.7$ \\
\cline { 2 - 4 } & 7 & $86.6 \pm 2.6$ & $228.0 \pm 6.8$ \\
\hline & 9 & $22.3 \pm 1.3$ & $61.3 \pm 3.5$ \\
\hline MM & 5 & $49.2 \pm 2.9$ & $134.4 \pm 7.4$ \\
\cline { 2 - 4 } & 7 & $69.3 \pm 1.8$ & $192.0 \pm 4.8$ \\
\hline & 9 & $19.3 \pm 1.2$ & $52.3 \pm 3.2$ \\
\hline
\end{tabular}

Table 4. Loading efficiency and loading capacity of microparticles loaded with inactivated influenza $A$ viruses during microparticle preparation

\begin{tabular}{lcc}
\hline $\begin{array}{l}\text { formulation } \\
\text { codes }\end{array}$ & $\begin{array}{c}\text { loading } \\
\text { efficiency (\%) }\end{array}$ & $\begin{array}{c}\text { loading capacity } \\
\text { ( } \boldsymbol{\mu g} \text { viral prot./mg } \\
\text { microparticles) }\end{array}$ \\
\hline LMv & $59.3 \pm 2.1$ & $1.3 \pm 0.05$ \\
\hline MMv & $93.7 \pm 1.2$ & $2.3 \pm 0.03$ \\
\hline
\end{tabular}

The antigen loading efficiency and loading capacity of the virus entrapped microparticle samples were indirectly determined by measuring viral proteins. After the formation of microparticles, the amount of viruses remaining in the liquid phase was determined using the Bradford method by using the standard plot given in Figure $1 \mathrm{~b}$, and loading efficiency and loading capacity of the samples were calculated as mentioned in methods (Table 4). The loading capacity and efficiency of microparticles prepared with $\mathrm{M}$-chitosan were found to be significantly higher than that of $L$-chitosan $(p<0.05)$.

\section{The Virus Loading Efficiency and Loading Capacity of Chitosan Beads}

The chitosan beads were only loaded with viruses by the passive adsorption method. The antigen loading efficiency and capacity of beads were determined by the titration of unadsorbed viruses with HA assay. Loading efficiency and capacity of chitosan beads were found to be lower than those of microparticles as shown in Table 5. Similar to the microparticles, the L-chitosan beads have higher loading capacity than the M-chitosan beads. In contrast, the loading efficiency and capacity of beads was higher at $\mathrm{pH}-5$ than that of $\mathrm{pH}-7$ and $\mathrm{pH}-9$ of the medium $(\mathrm{pH}: 5>7>9)(\mathrm{p}<0.05)$. The chitosan beads, prepared by coagulation in an aqueous TPP solution at pH-9 (LBB and MBB), were loaded more efficiently compared to the solution at $\mathrm{pH}-6$ (LBA and MBA). In addition, it has been shown that the drying method used for beads has a significant effect on the loading efficiency and capacity of

Table 5. Virus loading efficiency and loading capacity of chitosan beads. Beads $(20 \mathrm{mg}$ ) were loaded with purified influenza A viruses (1920 HAU) by passive adsorption

\section{Chitosan Beads}

\section{freeze-dried}

dried at r.t.

\begin{tabular}{|c|c|c|c|c|c|}
\hline formulation codes & loading pH & $\begin{array}{c}\text { loading } \\
\text { efficiency (\%) }\end{array}$ & $\begin{array}{l}\text { loading capacity } \\
\text { (HAU/mg beads) }\end{array}$ & $\begin{array}{c}\text { loading } \\
\text { efficiency (\%) }\end{array}$ & $\begin{array}{l}\text { loading capacity } \\
\text { (HAU/mg beads) }\end{array}$ \\
\hline \multirow{3}{*}{ LBA } & 5 & $17.1 \pm 0.8$ & $18.0 \pm 0.7$ & $7.5 \pm 0.4$ & $7.9 \pm 0.4$ \\
\hline & 7 & $9.5 \pm 0.3$ & $9.9 \pm 0.3$ & $4.1 \pm 0.2$ & $4.3 \pm 0.1$ \\
\hline & 9 & $7.2 \pm 0.2$ & $7.5 \pm 0.2$ & $3.1 \pm 0.2$ & $3.3 \pm 0.1$ \\
\hline \multirow{3}{*}{ MBA } & 5 & $10.0 \pm 0.6$ & $10.3 \pm 0.6$ & $5.4 \pm 0.4$ & $5.6 \pm 0.4$ \\
\hline & 7 & $6.6 \pm 0.3$ & $6.7 \pm 0.3$ & $3.2 \pm 0.2$ & $3.4 \pm 0.2$ \\
\hline & 9 & $5.4 \pm 0.2$ & $5.5 \pm 0.2$ & $2.7 \pm 0.1$ & $2.8 \pm 0.1$ \\
\hline \multirow{3}{*}{ LBB } & 5 & $26.2 \pm 1.3$ & $27.9 \pm 1.2$ & $10.8 \pm 0.4$ & $11.2 \pm 0.4$ \\
\hline & 7 & $14.3 \pm 0.4$ & $15.0 \pm 0.4$ & $6.3 \pm 0.2$ & $6.3 \pm 0.2$ \\
\hline & 9 & $10.4 \pm 0.2$ & $10.8 \pm 0.2$ & $5.2 \pm 0.1$ & $5.4 \pm 0.1$ \\
\hline \multirow{3}{*}{ MBB } & 5 & $17.5 \pm 0.8$ & $16.8 \pm 0.7$ & $7.1 \pm 0.4$ & $7.2 \pm 0.4$ \\
\hline & 7 & $10.6 \pm 0.5$ & $27.0 \pm 0.4$ & $4.7 \pm 0.2$ & $4.8 \pm 0.2$ \\
\hline & 9 & $8.9 \pm 0.3$ & $34.5 \pm 0.3$ & $4.2 \pm 0.2$ & $4.2 \pm 0.2$ \\
\hline
\end{tabular}



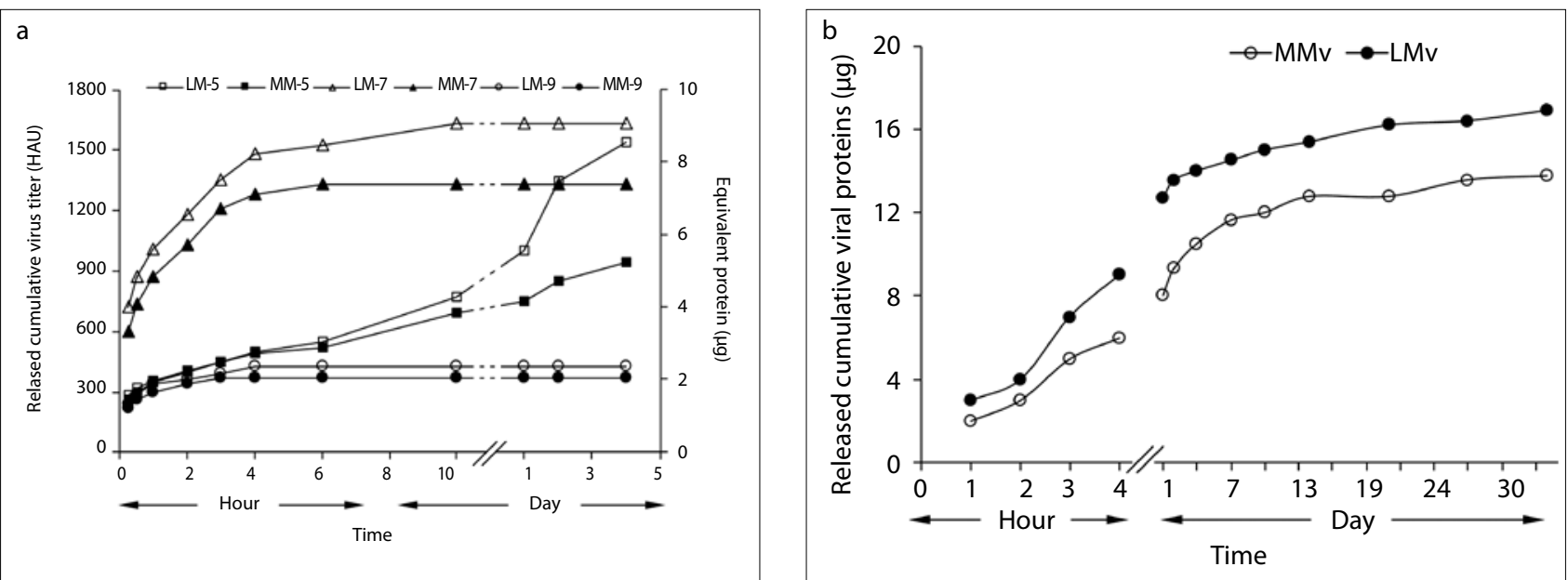

Figure 4. a,b. a) The release of viral antigens from chitosan microparticles that were loaded at different pH by passive adsorption; and b) microparticles loaded with viruses by encapsulation. The numbers added to the formulation codes of chitosan microparticles show the $\mathrm{pH}$ values of loading buffer.
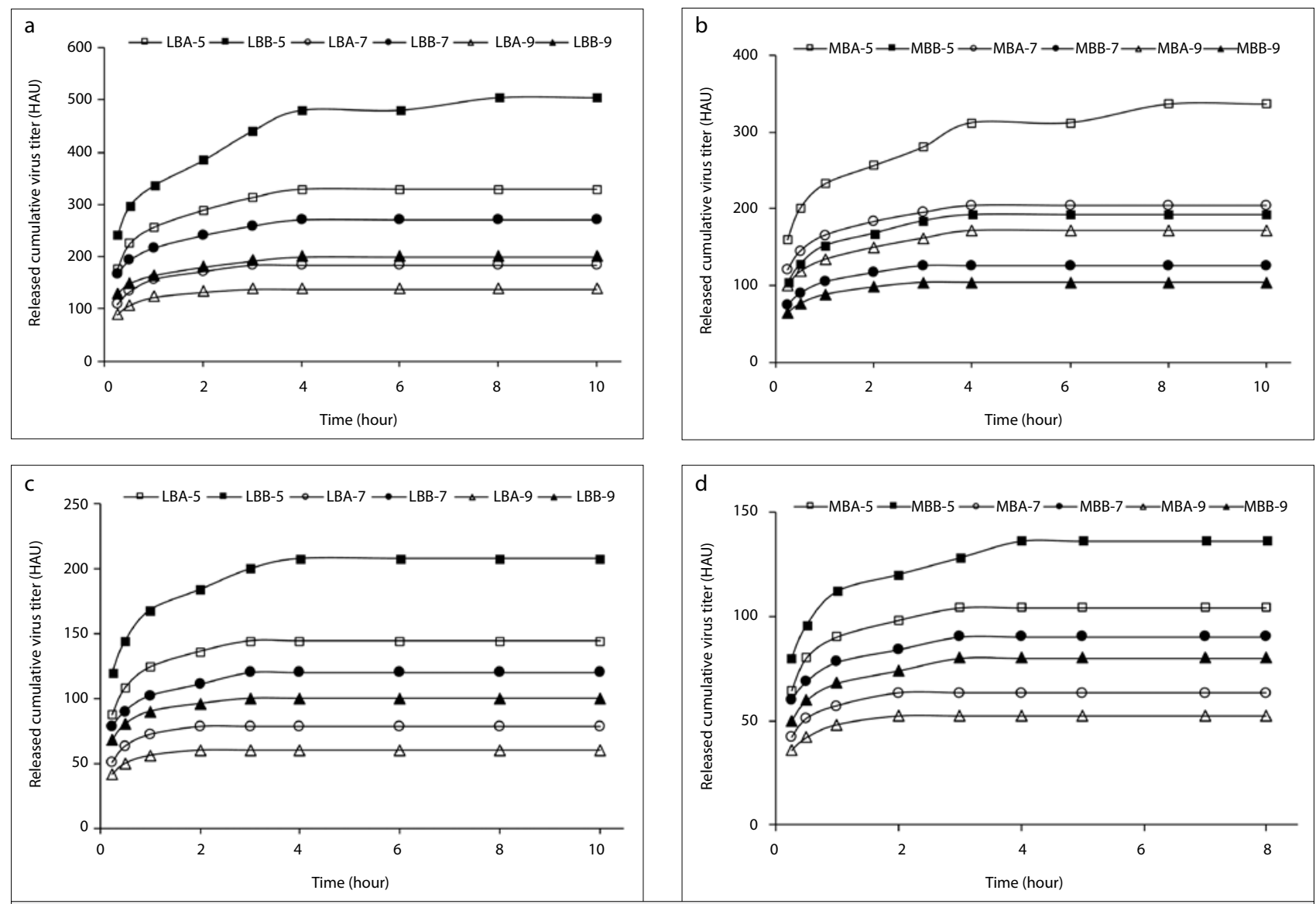

Figure 5. a-d. a) The viral antigen release from chitosan beads loaded at different pH. b) The beads prepared with L-chitosan and freezedried. c) The beads prepared with M-chitosan and freeze-dried. d) The beads prepared with L-chitosan and dried at r.t. The beads prepared with $\mathrm{M}$-chitosan and dried at room temperature. The numbers added to the formulation codes of chitosan beads show the $\mathrm{pH}$ values of loading buffer.

beads. The beads dried by lyophilization have at least 2 -fold higher loading efficiency and capacity than that of samples dried at room temperature.
The Release of Viruses from Chitosan Microparticles

Cumulative virus releases from chitosan microparticles loaded with passive adsorption or entrapment with viruses are given 
in Figure 4. The viruses adsorbed microparticles were released within 10 hours to 5 days depending on the $\mathrm{pH}$ of the loading medium. The viral antigens, which were loaded onto the microparticles at $\mathrm{pH} 5$, were released very slowly and continued for up to 5 days (Figure 4a). In evaluations based on the loading efficiency of microparticles; the cumulative ratios of released viruses from chitosan microparticles were calculated as $26-42 \%$ for the microparticles loaded at pH 5 (LM5 and MM5), 71-78\% for the microparticles loaded at pH 7 (LM7 and MM7) and 8592\% for the microparticles loaded at $\mathrm{pH} 9$ (LM9 and MM9) at the second hour of the releasing experiment. After 6 hours, the cumulative releasing ratios were found to be $35-55 \%, 92-95 \%$ and $\geq 95 \%$ for microparticles loaded at $\mathrm{pH} \mathrm{5,7}$ and 9, respectively. The releasing of viruses from L-chitosan microspheres was slightly higher than that of $\mathrm{M}$-chitosan microspheres. These results show that the loading $\mathrm{pH}$ is one of the most important factors affecting the rate of release of viruses from chitosan microparticles.

The releasing of viral antigens entrapped in chitosan microparticles was monitored by quantification of viral protein using the Bradford method as mentioned above. The cumulative releasing of viral proteins is given in Figure 4b. The viruses which were entrapped in microparticles were released very slowly and continued for up to 30 days. After 6 hours, the cumulative releasing ratios were found to be $27 \%$ and $31 \%$ for MMv microparticles and LMv microparticles, respectively. At the end of the 30-day period, the approximate cumulative release values for $\mathrm{MMv}$ and LMv had reached $63 \%$ and $57 \%$.

\section{The Release of Viruses from Chitosan Beads}

The loading of chitosan beads with viruses was carried out at different $\mathrm{pHs}$ (at $\mathrm{pH} \mathrm{5,7}$ and 9) such as microparticle samples. Then, the beads were suspended in PBS and left at $37^{\circ} \mathrm{C}$ in a shaking water bath to release the viruses. The quantity of viruses in samples taken from the liquid phase at defined intervals was determined by HA assays. The cumulative release of viruses from the chitosan beads is given in Figure 5. Although the loading efficiency and loading capacities were different, the release profiles of the virus antigens from the chitosan beads prepared in different conditions were relatively similar. The releasing of viral antigens from beads occurred more rapidly and about $90 \%$ of adsorbed antigens were released within 2-4 hours.

\section{DISCUSSION}

According to the World Health Organization report, infectious diseases constitute over $10 \%$ of the top 10 causes of deaths from 2000 to 2015 (36). Viral diseases have an important ratio among the infectious diseases in humans (37). However, the success rate of the prevention of viral infections is very low compared to bacterial diseases. The most effective way to prevent viral infections is viral vaccines, but they are not completely effective for a number of reasons. Therefore, a variety of new approaches are required to enhance the immune response and to ensure the long-term efficacy of the vaccines. The carrier polymers, which are biodegradable, non-toxic and allow the controlled release of antigens, are of great importance both in increasing the efficacy of the vaccines and in their ability to be used in the formulation of mucosal vaccines (38-40). Intensive studies have been conducted on the use of chitosan polymers in the formulation of vaccines as well as many other pharmaceuticals $(27,41,42)$. In this study, the potential of microparticles and beads prepared with chitosan polymers as a carrier of the virus antigen, were evaluated in in vitro conditions.

Influenza A viruses were produced in the allantoic cavity of embryonated hen eggs and purified by sucrose gradient centrifugation technique. A pure virus sample equivalent to 19200 $\mathrm{HAU} / 100 \mu \mathrm{l}$ (totally $500 \mu \mathrm{l}$ ) was obtained from 25 hen eggs (Figure 1). The purity of viruses was demonstrated both by polyacrylamide gel electrophoresis of viral structural proteins and by electron microscopic analysis of the virus particles (Figure 2). The viruses were used for incorporation and/or adsorption into the chitosan microparticles and beads.

Physical properties such as the sizes and surface structure of the chitosan microparticles and beads vary depending on the molecular weight of the chitosan, and the conditions applied for formulations (43). In the present study, two types of chitosan with different molecular weights were used for the formation of microparticles and beads. Although there was no statistically significant difference, it was found that the average sizes of the microparticles formed with L-chitosan were smaller than those formed with M-chitosan (Table 1). However, the entrapment of influenza viruses to the chitosan microparticles during the formulation resulted in significant increases in particle sizes ( $p>0.05$ ). Similarly, the average sizes of chitosan beads changed depending on the molecular weights of the chitosan and the conditions applied to form beads. It was determined that the beads formed with both $\mathrm{L}$ - and $\mathrm{M}$-chitosan in acidic $\mathrm{pH}$ were smaller than the beads formed in basic pH (Table 3 ). The beads prepared with L-chitosan were found to be smaller than those of M-chitosan. The most important factor affecting the sizes of the chitosan beads was the drying condition. The beads which were freeze-dried were 2-3 times larger than that of beads dried at room temperature. The drying process of chitosan beads also affected the porosity of the beads. Drying with a freeze-dryer resulted in more a porous and sponge-like structure of beads (Figure 3). The $\mathrm{pH}$ of the TPP used for ionic gelation was another factor affecting the pore structure of the beads. It was observed that the beads prepared in TPP at basic $\mathrm{pH}$ have a more porous surface structure.

Methods such as passive adsorption or encapsulation are utilized for the formulation of low molecular weight drugs, pharmaceutical peptides or vaccine antigens with different polymers to improve the bioavailability $(23,44-46)$. The characteristics of the molecules to be formulated are considered for the selection of the formulation method. The passive adsorption process is simple and just involves adding the solution of the molecules or the antigens onto the inert carriers such as microparticles and mixing in appropriate conditions (47). In some cases, the molecules can be adsorbed at high levels (up to $70 \% \mathrm{w} / \mathrm{w}$ ) 
onto suitable carriers (48). However, the burst release in adsorption-loaded microparticles is usually very high and, releasing is very fast. In the present study, it was found that the chitosan microparticles can adsorb up to $86 \%$ of the viral antigens added in the medium depending on the conditions. It was also found that the loading efficiency of chitosan microparticles significantly depends on the $\mathrm{pH}$ of the medium. The loading efficiency of microparticles was found to be around $20 \%$ at $\mathrm{pH}$ 9. The highest loading efficiency was achieved at $\mathrm{pH} 7$ (Table 3). The viral antigen loading capacities of chitosan microparticles prepared by encapsulation was also reasonably high (Table 4). About $80 \%$ of the viral antigens added to the medium were entrapped in microparticles prepared with M-chitosan. The entrapment ratio of viral antigens in L-chitosan microparticles was found to be $58.5 \%$.

The viral antigens adsorbed microparticles were released within 4 hours to 5 days depending on the chitosan type and the $\mathrm{pH}$ of the loading medium (Figure 4a). The viral antigens which were loaded onto the microparticles at $\mathrm{pH} 9$ were released very quickly and reached the maximum within 4 hours. In contrast, the viral antigens loaded onto the microparticles at $\mathrm{pH} 5$ were released very slowly and continued for up to 5-6 days. In the microparticles loaded with viral antigens at $\mathrm{pH} 7$, the release was faster than expected and reached the maximum value in 10 hours. It was concluded that the reason for the different release profiles of microparticles loaded at $\mathrm{pH} 5$ and $\mathrm{pH} 7$, despite their close loading efficiency, is the increase in the swelling capacity of the chitosan microparticles $(49,50)$ and changes in the charges of chitosan polymers and the viral antigens in the low $\mathrm{pH}$ buffer (51). Studies into increasing the efficacy of the vaccines have shown that the slow release of antigens formulated in microspheres enhances antibody production (52). Therefore, a slow, controlled release of antigen is preferred in cases of vaccine formulations. In this study, the viral antigens especially entrapped in the microparticles were released very slowly (Figure $4 \mathrm{~b}$ ). A very low initial burst release and a longer controlled release of the viral antigen from the chitosan microparticles was observed. The viral antigen release form both L- and M-chitosan microparticles continued for up to 30 days. Due to these properties, influenza A viral antigen-loaded chitosan microparticles especially prepared by entrapment are considered to be suitable for mucosal vaccine preparation.

The use of chitosan beads loaded with viral antigens may not be suitable for mucosal administration in in vivo. However, it can be considered as a model for monitoring the releasing characteristics of viral antigens from beads in in vitro. In this study, the chitosan beads were loaded with viral antigens with passive adsorption such as loading of the microparticles at different $\mathrm{pH}$. The highest loading efficiency of beads was defined at $\mathrm{pH} 5$ (Table 5). Both the loading efficiency and the loading capacity of beads were much lower than that of microparticles. The porous chitosan beads freeze-dried had approximately a 2 times higher loading efficiency and capacity than the beads dried at room temperature. Moreover, the releasing of viral an- tigens from beads occurred more rapidly. Approximately $90 \%$ of adsorbed antigens from all types of chitosan beads released within 8 hours.

As a conclusion, the chitosan polymers have great potential for the development of long-acting viral vaccines due to their unique properties such as biocompatibility, non-toxicity, bio-degradability and their immune stimulatory effects. The loading efficiency and capacity of the chitosan microparticles and beads for viral antigens varies depending on the type of chitosan polymers and the conditions applied for formulations. The results gave us useful information about the potential of chitosan microparticles as a carrier of viral antigens, which might be employed in in vivo studies as a mucosal vaccine.

Acknowledgements: The authors thank Dr. Seyhun Solakoğlu and Biologist Funda Durmaz (Istanbul University, Istanbul Faculty of Medicine) for their kind assistance for obtaining electron microscopic images.

Conflict of Interest: The authors have no conflict of interest to declare.

\section{REFERENCES}

1. Tharanathan RN, Kittur FS. Chitin-the undisputed biomolecule of great potential. Crit Rev Food Sci Nutr 2003; 43(1): 61-87. [CrossRef]

2. Kurita K. Chitin and chitosan: functional biopolymers from marine crustaceans. Mar Biotechnol (NY) 2006; 8(3): 203-26. [CrossRef]

3. White SA, Farina PR, Fulton I. Production and isolation of chitosan from Mucor rouxii. Appl Environ Microbiol 1979; 38(2): 323-8.

4. Elieh-Ali-Komi D, Hamblin MR. Chitin and chitosan: Production and application of versatile biomedical nanomaterials. Int J Adv Res (Indore) 2016; 4(3): 411-27.

5. Synowiecki J, Al-Khateeb NA. Production, properties, and some new applications of chitin and its derivatives. Crit Rev Food Sci Nutr 2003; 43(2): 145-71. [CrossRef]

6. Felt O, Baeyens V, Buri P, Gurny R. Delivery of antibiotics to the eye using a positively charged polysaccharide as vehicle. AAPS PharmSci 2001; 3(4): E34. [CrossRef]

7. Turan K, Nagata K. Chitosan-DNA nanoparticles: the effect of cell type and hydrolysis of chitosan on in vitro DNA transfection. Pharm Dev Technol 2006; 11(4): 503-12. [CrossRef]

8. Dastan T, Turan K. In vitro characterization and delivery of chitosan-DNA microparticles into mammalian cells. J Pharm Pharm Sci 2004; 7(2): 205-14.

9. Muanprasat C, Chatsudthipong V. Chitosan oligosaccharide: Biological activities and potential therapeutic applications. Pharmacol Ther 2017; 170: 80-97. [CrossRef]

10. Borchard G. Chitosans for gene delivery. Adv Drug Deliv Rev 2001; 52(2):145-50. [CrossRef]

11. van der Lubben IM, Verhoef JC, Borchard G, Junginger HE. Chitosan and its derivatives in mucosal drug and vaccine delivery. Eur J Pharm Sci 2001; 14(3): 201-7. [CrossRef]

12. Muzzarelli RA. Chitins and chitosans as immunoadjuvants and non-allergenic drug carriers. Mar Drugs 2010; 8(2): 292-312. [CrossRef]

13. Porporatto C, Bianco ID, Correa SG. Local and systemic activity of the polysaccharide chitosan at lymphoid tissues after oral administration. J Leukoc Biol 2005; 78(1): 62-9. [CrossRef] 
14. Li D, Fu D, Kang H, Rong G, Jin Z, Wang X, et al. Advances and Potential Applications of Chitosan Nanoparticles as a Delivery Carrier for the Mucosal Immunity of Vaccine. Curr Drug Deliv 2017; 14(1): 27-35. [CrossRef]

15. Elderfield R, Barclay W. Influenza pandemics. Adv Exp Med Biol 2011; 719: 81-103. [CrossRef]

16. Kilbourne ED. Influenza pandemics of the 20th century. Emerg Infect Dis 2006; 12(1): 9-14. [CrossRef]

17. Cunha BA. Influenza: historical aspects of epidemics and pandemics. Infect Dis Clin North Am 2004; 18(1): 141-55. [CrossRef]

18. Robertson JS, Inglis SC. Prospects for controlling future pandemics of influenza. Virus Res 2011; 162(1-2): 39-46. [CrossRef]

19. Marcelin G, Sandbulte MR, Webby RJ. Contribution of antibody production against neuraminidase to the protection afforded by influenza vaccines. Rev Med Virol 2012; 22(4): 267-79. [CrossRef]

20. Sawaengsak C, Mori Y, Yamanishi K, Mitrevej A, Sinchaipanid N. Chitosan nanoparticle encapsulated hemagglutinin-split influenza virus mucosal vaccine. AAPS Pharm Sci Tech 2014; 15(2): 317-25. [CrossRef]

21. Bitter C, Suter-Zimmermann K, Surber C. Nasal drug delivery in humans. Curr Probl Dermatol 2011; 40: 20-35. [CrossRef]

22. Shakya AK, Chowdhury MYE, Tao W, Gill HS. Mucosal vaccine delivery: Current state and a pediatric perspective. J Control Release 2016; 240: 394-413. [CrossRef]

23. Salatin S, Barar J, Barzegar-Jalali M, Adibkia K, Milani MA, Jelvehgari M. Hydrogel nanoparticles and nanocomposites for nasal drug/ vaccine delivery. Arch Pharm Res. 2016; 39(9): 1181-92. [CrossRef]

24. Doavi T, Mousavi SL, Kamali M, Amani J, Fasihi Ramandi M. Chitosan-Based Intranasal Vaccine against Escherichia coli O157:H7. Iran Biomed J 2016; 20(2): 97-108.

25. Rauw F, Gardin Y, Palya V, Anbari S, Gonze M, Lemaire S, et al. The positive adjuvant effect of chitosan on antigen-specific cell-mediated immunity after chickens vaccination with live Newcastle disease vaccine. Vet Immunol Immunopathol 2010; 134(3-4): 249-58. [CrossRef]

26. Volkova MA, Irza AV, Chvala IA, Frolov SF, Drygin VV, Kapczynski DR. Adjuvant effects of chitosan and calcium phosphate particles in an inactivated Newcastle disease vaccine. Avian Dis 2014; 58(1): 4652. [CrossRef]

27. Vasiliev YM. Chitosan-based vaccine adjuvants: incomplete characterization complicates preclinical and clinical evaluation. Expert Rev Vaccines 2015; 14: 37-53. [CrossRef]

28. Sonaje K, Chuang EY, Lin KJ, Yen TC, Su FY, Tseng MT, et al. Opening of epithelial tight junctions and enhancement of paracellular permeation by chitosan: microscopic, ultrastructural, and computed-tomographic observations. Mol Pharm 2012; 9(5): 1271-9. [CrossRef]

29. Sonaje K, Lin KJ, Tseng MT, Wey SP, Su FY, Chuang EY. Effects of chitosan-nanoparticle-mediated tight junction opening on the oral absorption of endotoxins. Biomaterials 2011; 32(33): 8712-21. [CrossRef]

30. Barrett T, Inglis SC. Growth, purification and titration of influenza viruses. Ed. Mahy BWJ: Virology: A practical approach. Oxford, IRL Press, 1985; pp 119-50.

31. Chrystie IL. Electron Mycroscopy. Eds. Mahy BWJ, Kangro HO. Virology methods manual. London: Academic Press, 1996; pp 91-107.

32. Sanders B, Koldijk M, Schuitemaker H. Inactivated Viral Vaccines. Eds. In Nunnally BK, Turula VE, Sitrin RD. Vaccine Analysis: Strategies, Principles, and Control. Berlin Heidelberg: Springer-Verlag Berlin Heidelberg, 2015; pp 45-79.
33. Shu XZ, Zhu KJ. Chitosan/gelatin microspheres prepared by modified emulsification and ionotropic gelation. J Microencapsul 2001; 18(2): 237-45. [CrossRef]

34. Lim ST, Martin GP, Berry DJ, Brown MB. Preparation and evaluation of the in vitro drug release properties and mucoadhesion of novel microspheres of hyaluronic acid and chitosan. J Control Release 2000; 66(2-3): 281-92. [CrossRef]

35. Mi FL, Shyu SS, Chen CT, Schoung JY. Porous chitosan microsphere for controlling the antigen release of Newcastle disease vaccine: preparation of antigen-adsorbed microsphere and in vitro release. Biomaterials 1999; 20(17): 1603-12. [CrossRef]

36. Global Health Estimates Technical Paper: Mathers C, Stevens G, Mahanani WR, et al.. WHO methods and data sources for countrylevel causes of death 2000-2015. 2017. WHO/HIS/IER/GHE/2016.3.

37. Howard CR, Fletcher NF. Emerging virus diseases: can we ever expect the unexpected? Emerg Microbes Infect 2012; 1(12): e46. [CrossRef]

38. Kaur L, Sharma A, Yadav AK, Mishra N. Recent advances on biodegradable polymeric carrier-based mucosal immunization: an overview. Artif Cells Nanomed Biotechnol 2018; 46(3): 452-64. [CrossRef]

39. MuZikova G, Laga R. Macromolecular systems for vaccine delivery. Physiol Res 2016; 65:S203-S216.

40. Mahapatro A, Singh DK. Biodegradable nanoparticles are excellent vehicle for site directed in-vivo delivery of drugs and vaccines. J Nanobiotechnology 2011; 9: 55. [CrossRef]

41. Arthanari S, Mani G, Peng MM, Jang HT. Chitosan-HPMC-blended microspheres as a vaccine carrier for the delivery of tetanus toxoid. Artif Cells Nanomed Biotechnol 2016; 44(2): 517-23. [CrossRef]

42. Ali $\mathrm{A}$, Ahmed $\mathrm{S}$. A review on chitosan and its nanocomposites in drug delivery. Int J Biol Macromol 2018; 109: 273-86. [CrossRef]

43. Mitra A, Dey B. Chitosan microspheres in novel drug delivery systems. Indian J Pharm Sci 2011; 73(4): 355-66.

44. Kreuter J. Nanoparticles and microparticles for drug and vaccine delivery. J Anat 1996; 189 (Pt 3): 503-5.

45. Vila A, Sanchez A, Evora C, Soriano I, McCallion O, Alonso MJ. PLAPEG particles as nasal protein carriers: the influence of the particle size. Int J Pharm 2005; 292(1): 43-52. [CrossRef]

46. Oliveira CR, Rezende CM, Silva MR, Pêgo AP, Borges O, Goes AM. A new strategy based on SmRho protein loaded chitosan nanoparticles as a candidate oral vaccine against schistosomiasis. PLoS Negl Trop Dis 2012; 6(11): e1894. [CrossRef]

47. Gupta S, Kesarla R, Omri A. Formulation strategies to improve the bioavailability of poorly absorbed drugs with special emphasis on self-emulsifying systems. ISRN Pharm 2013; 2013: 848043.

48. Ito Y, Kusawake T, Ishida M, Tawa R, Shibata N, Takada K. Oral solid gentamicin preparation using emulsifier and adsorbent. J Control Release 2005; 105(1-2): 23-31. [CrossRef]

49. Gupta KC, Ravi Kumar MN. Drug release behavior of beads and microgranules of chitosan. Biomaterials 2000; 21(11): 1115-9. [CrossRef]

50. Orienti I, Aiedeh K, Gianasi E, Bertasi V, Zecchi V. Indomethacin loaded chitosan microspheres. Correlation between the erosion process and release kinetics. J Microencapsul 1996; 13(4): 463-72. [CrossRef]

51. Kas HS. Chitosan: properties, preparations and application to microparticulate systems. J Microencapsul 1997; 14(6): 689-711. [CrossRef]

52. Demento SL, Cui W, Criscione JM, Stern E, Tulipan J, Kaech SM. Role of sustained antigen release from nanoparticle vaccines in shaping the T cell memory phenotype. Biomaterials 2012; 33(19): 495764. [CrossRef] 